\title{
Space and Turkey
}

\author{
Sait Yilmaz \\ Faculty Member of Political Science and International Relations, Yeditepe University, Istanbul, Turkey \\ Email: syilmaz39@hotmail.com
}

Received 2 June 2016; accepted 1 August 2016; published 4 August 2016

Copyright (C) 2016 by author and Scientific Research Publishing Inc.

This work is licensed under the Creative Commons Attribution International License (CC BY).

http://creativecommons.org/licenses/by/4.0/

c) (†) Open Access

\section{Abstract}

Around the world, increasing numbers of developing countries are investing in space-related technologies, seeking partners for space projects, and even constructing launch facilities. Those countries must overcome many hurdles to benefit the space independently for their own security and to make significant contribute to peaceful activities such as discovery of space, even if they use the advantage of turning up late in space studies. To see the concern between science and technology and space science and its technology within a country, it is sufficient to take a look at Research and Development ( $\&$ \&) investments supported by realistic policies. Incipient countries must consider the importance of international cooperation with experts and powerful corporations, to share the risk and cost and to create synergy, rather than following and copying the initiators in discovery of space, they should be able to develop new technologies and creative solutions with increasing international actors and projects, and be prepared for future with flexible and sensational plans. Turkey took important steps within the last 20 years but these efforts could not attain desired results yet. Turkey gained a position as satellite and satellite sub-system developing country in the world classification of active countries with initiated space projects. Besides not having sufficient space industry within country, most important obstacle towards Turkey is undeveloped social consciousness in this field.

\section{Keywords}

Turkey, Space Studies, Satellites, TÜBITTAK, TAI

\section{Introduction}

"Someday mankind will walk on skies without a plane, go to planets, maybe even send us messages from the moon... Our duty is, not to stay far too behind Western countries in this matter”. K. Atatürk’s Visit to Eskisehir Aviation Regiment, 1936.

Initially, space technology started as the race of two superpowers, which now became one of the most impor- 
tant issues in other countries' agenda. After World War II, when unrealistic space programs in USA faced with truths, it lost its enthusiasm as the time went by. This enthusiasm peaked with USA President John F. Kennedy's goal to send a human being to space and discover new worlds, also, Ronald Reagan's Star Wars Projects in 1983. In fact, with the conclusion of the space race, U.S. government interest in lunar missions waned after the early 1970s. Since the Apollo era, NASA's budget has fallen by about 50\%. At the Post-Cold War period, attention on space programs decreased. Root cause for this is human life increasingly depending on space-stationed capabilities especially in communication technology but because of being costly, public opinions' sympathy decreased (Putrich, 2008). Expectations turned towards to communication, forecast and accurate estimates for military fields rather than to be colonized in the space. Commenced in 1960's, space studies not only marked an era in communication, footage and guidance, also enabled mysteries of universe to be revealed or to interrogate the revealed ones via vehicles sent to the depths of the space. Development in space studies increased in 1990's and revealed new tendencies. Space provided an asymmetrical advantage for supply of technological ability to ensure national interests and financial power to cover big expenses. There is a need for vehicles in space for communication, guidance and gathering information. Space studies are increasingly important for Turkey to develop her national power in a more independent way for the future military scenarios as well as civilian requirements. In this article, after determining the situation of importance and place of space studies in world, we will investigate Turkey's studies on this field.

\section{Space and Space Studies}

\subsection{What Is Space? And It's Importance}

Space geopolitics is an undiscovered doctrine area. Space offers its own limitations but also surprising opportunities. When we talk about space, with general definition we are talking about a space $100 \mathrm{~km}$ above from earth but this starting line is no longer proper for space vehicles to work, in this place physics (Orbital Mechanics) steps in. Generally, air and space seem like continuation of each other and in the most of the strategies analyses the term "aerospace" is in use. Today, space and air are acknowledged as a whole, this area named as "aerospace". Events in world and its surrounding atmosphere happening in boundaries of rule and there are international laws to regulate this area. The area beyond space is named as "outer space". Space starts at the above of atmosphere and continues to infinity. However, in practice, space area for satellites represents between 90 miles and 22.300 miles altitude. Space vehicles categorized as satellites in orbit, earth stations in contact with satellites, bases oriented to perform space duties, communication facilities and other ground systems (FM 3-14, 2005). Considering for air vehicles' aerodynamic rules to fly, atmosphere means the highest altitude for vehicles to fly. This altitude is between $100.000-120.000 \mathrm{ft}$. $99 \%$ of air mass creating the atmosphere is below this altitude. The lowest altitude for a satellite to fly is $150 \mathrm{~km}$ that is accepted as the spaces lowest altitude. Currently, over 880 satellites of 50 countries are active in space. Lowest altitude an elliptic orbited satellite can pass over ground is $129 \mathrm{~km}$ (Yilmaz, 2001).

While the United States remains the leading actor in space today, it faces challenges to its future supremacy from both Russia and China. Russia remains the second most capable space power, next to the United States, and still leads in a number of categories. While currently well behind the United States, China is also emerging as a significant space power. China is committed to a major expansion of its program of human spaceflight, commercial, scientific, and military capabilities as well. Many US military analysts assume that China will eventually develop a major space weapons program, due to what one expert calls "strategic logic" (Gouveia, 2005). Europe as a whole already possesses a variety of space means that can be of significant military value. Space was at one time the sole domain of the wealthiest developed countries. But the last couple of decades of the twentieth century and the first decade of the twenty-first witnessed an increase in the number of countries with state-supported space programs. No fewer than 25 developing states possess active national space programs with proven independent launch capability or concrete plans to achieve it soon (Harding, 2013). Examples like Iraq, Bosnia, and Libya are proving to despair of countries not using space. Considering its geographical position, located between crisis in world, Turkey took considerable steps within 20 years even though it is late and slow.

In some resources area between earth and sun is named as "low-slung space"; vehicles trajectory moving in this area categorized by their height, slope and shape. The ideal trajectory for Turkey is ground coherent because it gives access for all of its area of interest. Active communication with polar zone can be provided via placing 
elliptic satellites in orbit. Countries like USA and Russia, who has interest in this area, use it. Low ground trajectories are adopted by establishments such as Iridium and ORBCOM to provide commercial audio and date communication services. In the low ground trajectory, because it is impossible to contain a wide area with one satellite; many satellites must create a "constellation".

Although, at the beginning of the space age, the space discovery projects were only in Russia's and few developed countries monopoly; space became a more democratic place with other countries desire to study in this field. This is a conclusion of technological improvements and political changes in global level. As the countries' space programs improve, more financial resources will be provided for space science, space technology and space discovery programs and consequently; new faces will be involved to space club. The United States represents about 80 percent of worldwide public expenditures, while it is responsible for almost 95 percent of military spending on space (Pasco, 2009). Each year, 38 billion of 50 billion of global expenses made for space studies are covered only by USA. While the competitors of USA are China and Russia, The European Union aims to improve its long-term space capability. China and India are increasing their investments for space. Malaysia, Thailand, Czech Republic and Colombia also established their space agencies. USA's main launching and control systems are located in Kennedy Space Center in Florida, Cape Canaveral Station and Vandenberg Air Base in California. Europe's Arianne rockets are in French Guiana in South America. Russia has a space center at Baykonur Base in Kazakhstan. Intelsat provides USA's space systems communication and Europe's is provided by Europe Space Operations Center in Darmstadt.

\subsection{Space Studies}

Journeys including humans to go beyond the earth, to new discoveries and to search for other living areas are right around the corner. Current example for this, Rosetta space duty performed with international cooperation by Europe Space Agency (ESA). Japan's Hayabusa2 space vehicle took on a similar duty and started its journey. USA continues to work on to send catch-bring meteors duty to space. China and India, continues to going and landing activities on Moon and Mars successfully. Figure 1 shows that Chinese researchers examine the scorched Chang'e 5-T1 return capsule after it landed successfully in Inner Mongolia having travelled around the moon and back. The main goal of the NASA (National Aeronautics and Space Administration), which creates the biggest budget each year (In 2013, approximate 20 Billion Dollars, in general 43.7 Billion Dollars), is toperform work intended to discovery of space and scientific invention to maintain USA in the field of space and aeronautics. The main goals within discovery of space are meteors and developing flights to Mars with humans. NASA develops space vehicles with using cutting-edge technologies for this journey. To try all this technologies, operations are continuing on the space duty to catch a meteor in the solar system in the year of 2020 and place it in a trajectory around the moon. Astronauts will work on this meteor to try to gather information on the universe and beginning of the earth by inspecting billions of years old unimpaired creations. Also, trying to find answer

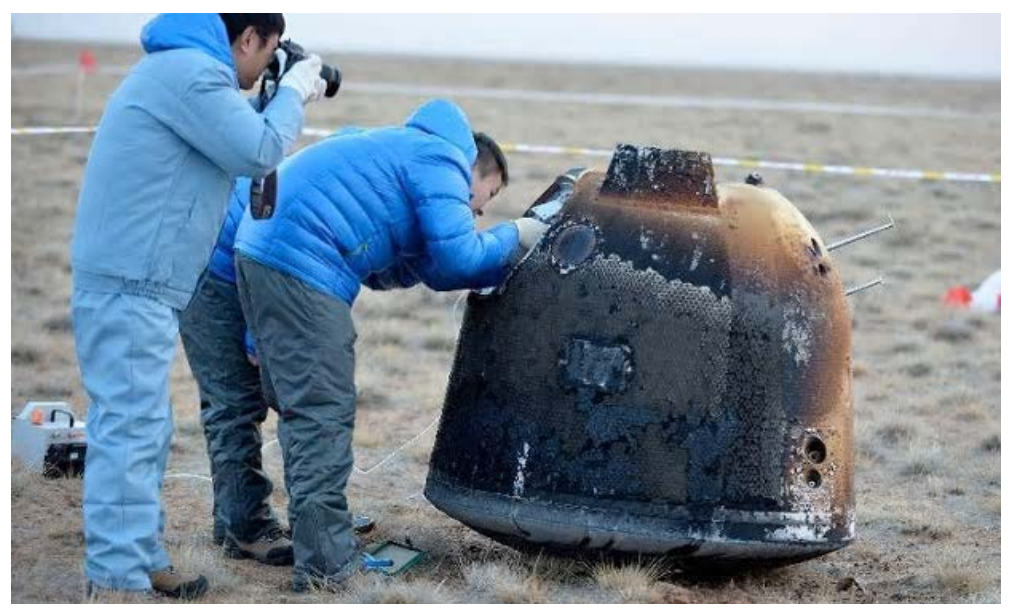

Figure 1. China probe flies around moon. Source: The guardian, China probe flies around moon and back in first such mission since 1970s (November 2, 2014). 
to the question; "is there any other place to live, except Earth?".

Similar works to USA are made by ESA and main countries Germany, France, Italy and England; Russia, Japan, India and Canada. China continues to work on improve their space technologies with and without humans synchronously. These works have a few goals. The most important one is to develop cutting-edge technologies to orient with harsh space conditions. To be ready to be a civilization lives in the Earth's Orbit and deep space. For this purpose, it is critical to procure life essentials such as water and precious minerals in the space. Turkey is still not in these activities. Rosetta Space Duty is inspecting a comet to provide an insight to the begging of the universe with 1.7 billion dollars of budget, over 30 years of project duration, over 10 years of space traveling and the in the course of events with a landing vehicle with only 60 hours of battery life.

Whether in USA or in other countries with power in space studies, the content of the work and budget are interrogated frequently. Occasionally stated as this budged could be used for more basic needs (World hunger, basic education). However, countries with power in space stated that the budget reserved for space studies brings more than spent to country and the world and it presents high value-added products. USA owes being World leadership to its leading work in spaces studies. USA, took steps to involve private sector to space studies with practicing a program since 1990's. Today, most of the space programs made by Boeing, SpaceX, Orbital Sciences, Virgin Galactic, Sierre Nevada, in cooperation with NASA. In the fundamental of these works, the goal is to reach space economically. USA's investment on spaceship and international space stations criticized occasionally. In the last 40 years, investment budget on these studies is 300 billion dollars and portion per capita considered as only 3 dollars. Gaining of these studies remarked as 8 - 10 dollars per capita (Aslan, 2014). Consequently, profit and employment of USA's space studies are much more greater than investment expenses.

For countries manages their acquisition policy in line with their own space system type (Table 1). Besides countries with power in space, small and limited satellite systems starting with cube satellites, enables underdeveloped or developing countries to practice space studies. The civilian space sector is composed of a variety of organizations and actors concerned with creating and implementing a national civilian space policy. International cooperation is an important feature of a civilian space program. Development in automotive and user electronic sector simplicities made it easier to make small, dependable and economic space systems. Making hundreds of kilograms satellites is no longer needed to procure one-meter sensibility of ground display resolution. In addition to states, enterprises', especially SME's, space studies increases around the world. An attempt to collect contribution from citizens has been started in England.

\section{Space Security}

\subsection{Context of Space Security}

The space security is not the interests of particular national or commercial entities, but the security and sustainability of outer space as an environment that can be used safely and responsibly by all. From communications to financial operations, farming to weather forecasting and environmental monitoring to navigation, surveillance and treaty monitoring, outer space resources play a key role in the activities of all nations. In recent years, we witness the effects of outer spaces on human security and economic progress increasingly. Communication and Internet usage provided by satellites globally contributes not only on economies but also on civil society in

\section{Table 1. Space system type examples.}

\begin{tabular}{|c|c|c|}
\hline 1. & Space-based systems & Satellites \\
\hline 2. & Ground-based systems & $\begin{array}{l}\text { Satellite command and control (C2), launch } \\
\text { C2, ground station payload data processing } \\
\text { stations, space surveillance stations, } \\
\text { command and control systems }\end{array}$ \\
\hline 3. & Satellite launch vehicle systems & $\begin{array}{l}\text { Boosters, upper-stages, payload processing } \\
\text { facilities, space launch facilities, ground } \\
\text { support equipment }\end{array}$ \\
\hline 4. & User equipment & $\begin{array}{l}\text { Hand-held user terminals, data reception } \\
\text { terminals, user terminals }\end{array}$ \\
\hline
\end{tabular}

Source: Department of defense, national security space acquisition policy, “Guidance for DoD space system acquisition process,” Number 03-01 (Washington, DC: US Department of Defense, 2004), p. 7. 
social area. Besides receiving warnings and help for natural disasters, images acquired via satellites also eases to track long-term dangers like climate changes. Commercial use of space most used in scope of television and image capturing services but because of economical crises, satellite operators are obligated to cooperate. In addition to being economically important, commercial space activities are vital to national security, primarily in three ways. First, commercial space activities provide products and services to the defense and intelligence resources. Second, satellite telecommunications support vital activities like transportation and banking. Finally, commercial satellites are essential to daily commerce (Linster, 2009).

Space security can be defined as sustainably and reliable access to space and protection of threats of space (Jaramillo, 2010). Based on current trends, the most important security problems could be encountered are (West, 2008): (1) Sustainability of space functions; (2) Increasing in space actors; (3) Spread of space technologies and serve for undesirable purposes. Today, academic studies on space are mainly focused on space security, to use space with peaceful purposes and prevent armament race in space. Space is not only for scientific studies but also for many fields like communication, track natural disasters and environmental issues, telemedicine, distance learning. Space security indicators may be listed under three different goals set as purpose (Eisenhower Insitute, 2004).

-Sustainability of space working place:

1) Space areas must be accessible;

2) Awareness of situation in space;

3) Implementation of space laws, politics and doctrines.

- Types of actors in space and their use of space:

4) Civil space programs and global practices;

5) Commercial space;

6) Space support for military operations.

- Status of space technologies:

7) Protection of space systems;

8) Making space systems unusable;

9) Capability of attacking based on space.

The most critical challenge to the security and sustainability of outer space continues to be the threat posed by space debris to spacecraft of all nations. Experts estimate that there are more than 500,000 objects with a diameter larger than one centimeter and several million that are smaller. Until the year 2035, debris amount in earth's orbit will be decupled (MacDonald, 2009).

The most variation of supremacies about space is based on; sensibility of real-time or close to real-time responding, create more capacity, protect interests on space and prevent rivals to exploit space products and services. At the present, the two most basic subjects are increase awareness and space ruins. The first danger to talk about space is increasing in debris in space and EU's regulations on this are not sufficient. Another issue of concern is the increasing need for broadcast waves and communication bands and the start of satellites to crash in air due to their increasing population can be counted as another danger. In return, capability intended space is not improved rapidly. Even in the USA, situation awareness capability is slowed down due to bureaucracy. Mainly, improve in defense observing and satellites capabilities are seen.

Furthermore, space brings specific problems as well. First of all, initiator space countries-USSR and USAinvested large amounts to attain these capabilities. Space science has spread in a large scale and moved forward, many countries found a chance to penetrate to this science. Secondly, space flight capability needs a large foundation and the vehicles are quite expensive. Thirdly, not everywhere is capable for launching space vehicles. Here, the importance of geopolitics comes in sight for the first time. If a country is not capable of launching due to their geographic location, then she needs to form an alliance with a capable country. A part of countries using space programs, except free market conditions, made providing space launching capability via forming an alliance or at least via building friendly relationships their national interest.

There are two primary sources of international law on space: customary law, and international agreements. There are four main treaties that make up the specialized body of space law: the Outer Space Treaty (1967), the Rescue and Return Agreement (1968), the Liability Convention (1972), and the Registration Convention (1975). All major space powers are party to all four of these treaties. Most of the principles in these treaties are generally accepted as customary international law binding on all nations, even those nations that are not party to them. The ending of armament at space is one of the highest priorities. For this purpose, after 1960's and 70's to 
present, to make these kind of agreements became necessity. While China and Russia, working together against USA's taking measures in multilateral way to space disarmament; USA is staying off by reasoning review its space policy. Within the EU disarmament conference in 2008, China and Russia's commence on a draft of agreement to prevent armament in space, threat against the objects in outer space or draft agreement on power usage are some of the works in this field.

At the EU level:

-Within EU General Assembly, The Disarmament and International Security Committee and The Committee on the Peaceful Uses of Outer Space (COPUOS). to $\mathrm{CD}$.

- The Committee on Disarmament (CD) and Prevention of an Arm Race in Outer Space (PAROS) attached

- International Telecommunication Union is the main international institutions on space security.

\subsection{Space and Soldiers}

The post-Cold War period has witnessed an amplification of the uses of space. The importance of space goes beyond just more commercial satellites providing a greater number of people with television, internet, and telephone services. Space-based assets are considered by modern militaries to be indispensable "force multipliers", which enhance their capabilities through reconnaissance, weather surveillance, and even real-time imaging (Harding, 2013) (See space surveillance capabilities of countries at Table 2). In case of not controlling space, it is a high possibility to lose war against the ones who can control the space. The key technologies for modern armed forces are Global Positioning System (GPS) and satellites. During the World War II, thousands of missiles required to be thrown to destroy a factory. Today, missiles guided by GPS' took place. To make space open for warfare would make important changes in war doctrines and means.

Table 2. Space surveillance capabilities.

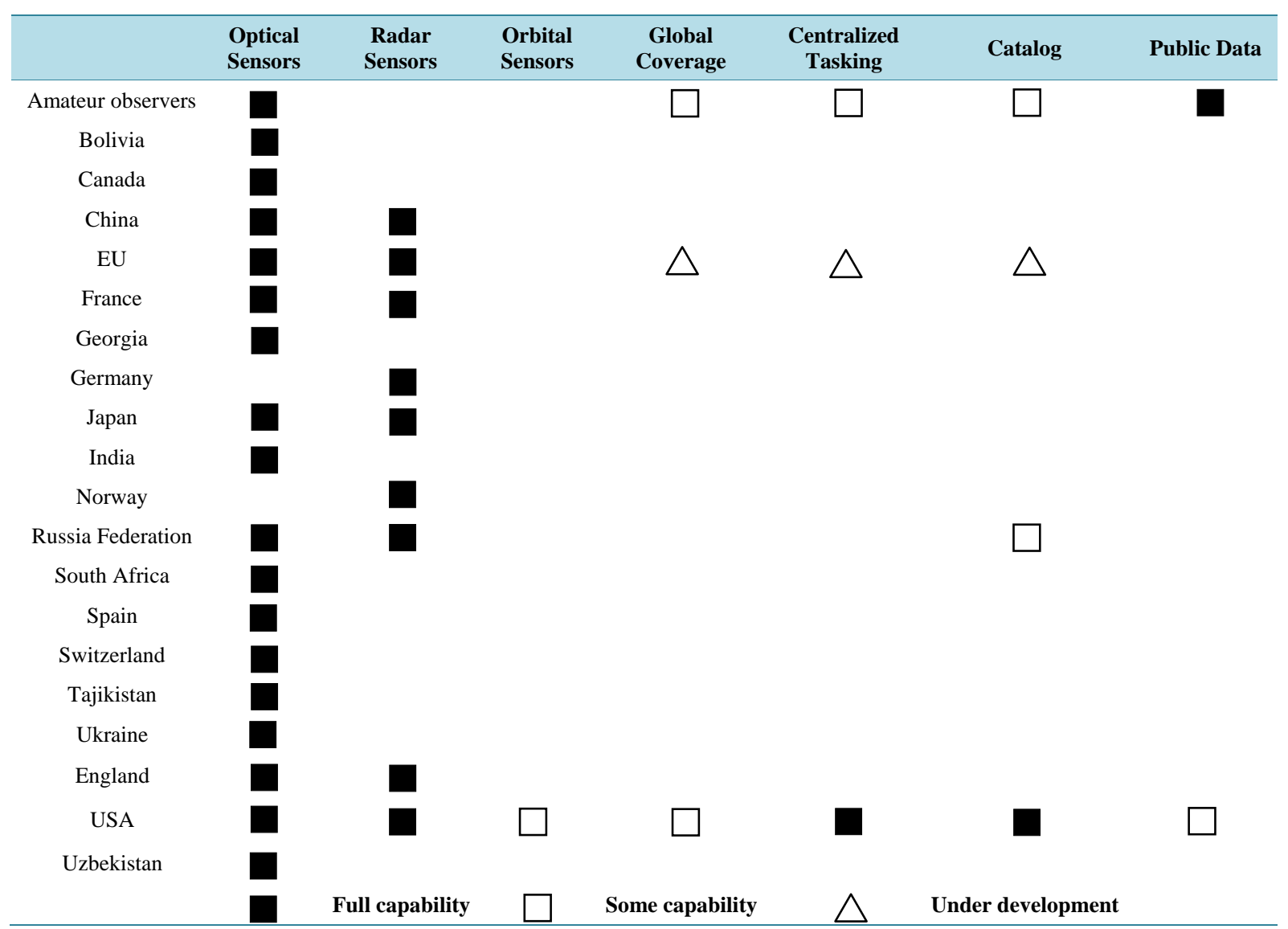

Source: Jaramillo (2010) space security 2010. ontario; pandora press; 2010: 52, Figure 2.1. 
As we look from the point of armed forces, capabilities on space in order; providing armament platform at space, establish a defense structure for preventing usage of space for making attacks, to form a satellite supported early identification, warning and control systems. Also, these countries establishing Space Command in their Military Organizations and Air Forces is taking an active part in it (Göker, 2003). Space operations are divided into two as; control of space and practice of space, and the types of operations are listed below:

- Satellite communication;

- Satellite position, speed and timing activities;

- Observing environment;

- Intelligence, surveillance, reconnaissance (ISR) based on space;

- Missile warnings.

At the recent, power projection based on USA mostly relies on ABM program and is not giving place to hypersonic vehicles and kinetic energy weapons based on space, yet. The short-term plan is using ABM inhibitors within the context of ballistic missile defense system.

According to USA Ministry of Defense, four working fields are present within military space operations (Lewis, 2004); control of space (preventing rivals' intervention for practicing space vehicles freely), space power defense operations (improvement of intelligence and space support in the scope of collective movement), space support (launching, placing in orbit, commanding and controlling vehicles used within space operations), applying space force (to shoot a land target via military armed forces used in space or via space). Applying force includes Anti Ballistic Missile (ABM) and space power projection. USA established Space Command and now pursues to establish a separate Space Force. Until recently, the first thing to come to mind when it said space capabilities was usage and maintenance of information (early warning, intelligence, guidance, weather forecast, communication and intelligence flow) necessity for increasing activities of military operations on earth. USA Space Warfare Center and Space Laboratory's primary effort is provide necessity information support for the pilot in planes cockpit to shoot and see his/her target quickly or to detect rivals missiles location and steer own missiles incisively. For this reason, important improvements provided in high definition images and infrared censors. But, attentions turned to battles to be held in space.

Turkish armed forces, set target to have active force in space, is getting ready to establish fifth force "Turkish Space Forces' after Ground, Air, Naval Forces and Police Soldiers Command. Accordingly, addition to existing Göktürk 2 satellite, Göktürk 1 and Göktürk 3 satellites will be launched and with this, Turkey’s requirement for intelligence would be solved and duty will start” (Erturan, 2015). Important changes are foreseen in Air Force Command's force structure. Space area will be actively used for especially in discovery and denunciation fields with Space Force and Turkey's approaching satellites. Besides military personnel, civil space scientists are expected to be in charge in the force. In the scope of space grounded discovery architecture, besides electro optic satellite systems, it is aimed to attain capability to gather imaged independently from geography, day and night, every weather condition, with approaching radar observing satellites.

\subsection{Space Balance of Power Changes in Favor of the East}

Throughout the Cold War period, Soviet space studies were representing one of the most important rivalries in technology and industry. However, Russia Federation's increasing problems in space industry became more apparent after the Cold War period. Failures encountered with launching two cargo space vehicles and Mexican communication satellite, were the proof (Jones, 2015). Russia's main space launching place is the Baykonur Space Base at Kazakhstan and all astronauts and cosmonauts are arriving to the International Space base from this base. Russia pays respectable amount of rent for Baykonur and Russia needs to build good relationship with Kazakhstan to use this base. Although Russia started to build Vostoçni Cosmodrome as a backup for Baykonur, but the construction has stopped because employees are not receiving wages. Russia's military satellites are getting older day by day and did not send anything beyond earth after the collapse of Soviet Union. Furthermore, two attempts on going to Mars have failed. But, Russia will continue to be one of the most important partners of the International Space Base until 2024. While, Russia's future space plans are uncertain, it is accurate to say the bright days are over.

China, India and Japan steps forward as the greatest space force of the Asia. Originally, Asia's expectations on space technologies were to draw maps of agricultural estates and to use satellites for communication of humans scattered into a wide area, not sending humans to Mars. Japan became a partner of The International Space 
Station under the favor of its friendly relations with USA. China sent its first astronaut to space in 2003, and now planning to land on Mars in 2030. China's space studies triggered its rival, India, and India starts astronaut capsule testing task. With a powerful electronic base, South Korea sends its satellites with foreign missiles. The first Korean astronaut to land on Space Station was Soyeon Yi. Nowadays, South Korea tries to improve its and Russia's launching base and mentions about sending astronaut to the Moon. North Korea sent its satellite to space long before South Korea. Thailand, Malaysia, Singapore, Indonesia, and other economically developed countries in Asia have satellites due to their technologies. China wants to compete with the main actor of space industry, USA, while its studies unwind. China's space base could step in while the current International Space Station expires. USA, excludes China from scientific space studies due to security problems, rather than cooperate (Jones, 2015).

NASA began its first test flights aimed to improve Orion Spacecraft for astronauts to go deep space. USA is not sending astronauts to space since space shuttles retired in 2011 and not planning to send until 2021. Also, nobody knows what USA will do with Orion and the financial resources are not guaranteed for a long-term project like as such (Jones, 2014a, b). On the other hand, space studies lost its significance and politicians pursue local projects to gain votes. India will do space capsule test soon. Japan started a task to collect pieces from asteroids. In brief, space balance of power changes in favor of the East.

Two commercial attempts on traveling above atmosphere end up with calamity. Orbital Sciences Corporation's missile called Antares exploded short after departure while carrying materials to Space Station due to agreement with NASA. During Virgin Galactic's space traveling, one of the test pilots has died (Pillar, 2014). Even it's within commercial industry, these developments made profit-oriented companies' positions controversial. Modified version of Soviet engine from 1970's used in Antares missile. Commercial Companies decreased values to gain more profits and this initiated controversies. Many people think space travels for fat-rich people and the societies' urgent needs are different. At the same time, considering discoveries made in last 20 years, to find new things to change the World's destiny in 50 years is not a theory to underestimate. The world still awaits a Mahan for the space age, a theorist who can articulate how space power contributes not only to national security and prosperity, but creates a lasting and significant benefit for all of humankind (Wirtz, 2009).

The NASA contract to fly cargo to the station in unmanned rocket ships has attracted bids from high-profile companies in what analysts say is another indication of commercial spaceflight's recent renaissance (Davenport, 2015). The money, or interest, in space wasn't there just a few years ago. SpaceX has rejuvenated public interest in space, and is already plotting a Mars mission. Forbes is doing profiles on asteroid mining startups. A coalition of private companies is building a spaceport in New Mexico. It's the most exciting period for space exploration since the last moon mission in 1972. It's 2015, and space is cool again.

\section{Turkey and Space}

\subsection{Turkey's Space Studies}

Even gaining acceleration in the past ten years, current status and expense level is distant from becoming significant force in the field of space. Space studies in our country officially put on the agenda in early 1960's, and gained acceleration since 2005. This process started with buying and operating satellites activities. As the result of comprehensive studies by public and private institutions, a space program and budget announced by BilimVeTeknolojiYüksekKurulu (BTYK) in 2005 and projects and expenses started in this direction. A defined budget for R \& D enables different magnitude national institutions to do business in the space field. Today, Turkey focused on developing major ground observation and communication satellites. National observing satellites RASAT and Göktürk 2, improved as a part of this program. Simultaneously, two cube cost-efficient satellites developed by Istanbul Technical University, placed on orbit. Also, started to design national satellites, to develop regional location and timing satellites this year. Alongside, it's aimed to have capability to access space. According to data provided from Euroconsult 2014, Turkey's expenses on civil space program are 67 Million Dollars (150 Million TL) (Aslan, 2014). Countries we can take as an example, such as Brazil, makes 505 Million Dollars expenses each year on civil space programs, South Korea makes 303 Million Dollars and Mexico makes 190 Million Dollars. Expenses made by the top ten countries in world are over 500 Million Dollars each year.

Turkey, Brazil, Thailand, Malaysia, South Africa and other new developing countries started with making cost-efficient space technology transferring programs and to make cooperation with more developed countries. Turkey started its first space programs with procuring TURKSAT series satellites from abroad, and local satel- 
lite operator TURKSAT bought 7 communication satellites within 16 years and now planning to buy another satellite until 2015. In parallel, Turkish engineers and technicians took technology transfer and on the job training in scope of BİLSAT observing satellite project and the first infrastructure and capability for countries observing satellites started to get a shape. Ideas and opportunities on producing local satellites appeared in 2004 and squad working in BILLSAT project, started producing Turkey's first ground observation satellite, RASAT. RASAT satellite, launched and placed on orbit from Yasny Launching Base in Russia in 17 August 2011 as Turkey's first ground observation satellite, and following, started to put in use and calibration. RASAT is the first observing satellite produced and designed in Turkey. It is the Turkey's second remote sensing satellite after BİLSAT. Turkey continues to produce differential observing satellites and nationalize many satellite subsystems with gained experience from RASAT and BILSAT projects.

Developed by collaboration of TÜBITAK SPACE and TAI, Göktürk 2 Discovery satellite, launched from Jiunquan Launching Base in China in 18 August 2012. Satellite's duty computer and software produced by Turkish engineers in Turkey. It's the first produced satellite to capture high definition images of Turkish Republic's history. In scope of Göktürk 2 project; technology for space and satellite systems, developing experts and subsystems, providing public institutions and establishments' observing and researching needs by national capabilities are aimed. Additionally, BİLGE, a flight computer designed and developed by TÜBİTAK SPACE, real-time image compression equipment GEZGiN (GerçekZamandaGörüntüIşsleyeN) and X-Band communication modules are being tested.

TÜBİTAK SPACE is the leading institution of Turkey in space technologies. This institution started its space technology studies by making transfers about mini satellites with England's settled company SSTL, in scope of BILLSAT experimental research satellite project in 2003. Following the matter of learning basic capabilities with Mini satellite design and producing, RASAT project produced without any foreign support and consultancy. TÜBİTAK SPACE makes medium-term space research program plans in parallel to international research programs accepted by BTYK (Tübitak UZAY, 2005). At the same time, capabilities are gained for space discovery duties. For example, a duty computer developed for interplanetary duties, equipment and power systems to work in high radiation environment are being produced and software suites are being developed. Also, investing for produce and test of the electric impulsion systems' subsystem has started. Simultaneously, Middle East Technical University and Ukrainian Institutes makes mutual projects on developing Hall affected impulsion systems. TÜBİTAK SPACE attends European Union's 7. Framework with many projects and offers proposals with foreign partners. Plus, TÜBİTAK SPACE uses European Cooperation for Space Standardization (ECSS) and Consultative Committee for Space Data Systems (CCSDS) standards for compatibility for international duties in future. TÜBITAK SPACEcalls all beginners and already developed institutions and establishments that want to discover space, work in space field for sake of humanity and develop practices to work together and develop assertive but well-conceived duties.

The development and spread of space systems revealed new usage area, aim, reason for these systems. As in the World general, satellites generally used and developed for military purposes and civil practices in Turkey. Some establishments in Turkey started to benefit satellites in their field since 1980's. At first, space industry was not available in our country. But, as conclusion of using satellites and presenting affiliated services to public, space industry brought to country's agenda. Turkey's interest in satellite designing started with TÜBİTAK SPACE (BILLTEN)'s designing a research satellite. In continuation, relevant institutions and establishments started to develop space studies in corporation with domestically leading TUSAŞ-TAI.

1. Activities of Türksat S.A. operating communication satellites:

- Türksat 1B satellite, launched in 1994.

- Türksat 1C satellite, launched in 1996.

- Eurasiasat established by Türk Telekom in association with Aerospatiale, which produced Türksatsatellies in 1996.

- Türksat 2A satellite launced in 2001.

- Satellite activities were being performed under the structure of Türk Telekom, after the privatization of Türk Telekom in 2004, Türksat S.A. established as a new company.

- Türksat 3A satellite launched in 2008.

- Tender for Türksat $4 \mathrm{~A}$ and $4 \mathrm{~B}$ satellites started.

- Türksat-6A work started.

2. Activities of State Meteorological Service (SMS) General Directorate: 
- State Meteorological Service (SMS) attended European Meteorology Satellites Association (EUMETSAT) as a founding member in 1986.

3. SMS benefits EUMETSAT organizations satellites in meteorology.

4. TÜBİTAK Space Technologies Research Institute’s (TÜBİTAK-SPACE; old name TÜBİTAK-BİLTEN) Activities:

- An electro-optic monitoring carrier BILLSAT satellite, developed with a company that provides foreign technology and launched in 2003.

- Ongoing authentic satellite subsystem designing.

- Developed by TÜBİTAK SPACE and TAI in collaboration, Göktürk 2 discovery satellite launched in 18 December 2012.

- RASAT, sent to space from Russia Federation’s Yasny Launching Base in 17 August 2011.

- Works concerning Göktürk 1 and Göktürk 3 are started.

5. TAI-TUSAŞ Space Activities:

- Activities intended to satellite systems are started at TUSAŞ in early 2000.

- TUSAŞ produced mechanical pieces for a camera developed by TÜBİTAK SPACE in 2001/2002.

- TAI-SAT performed cognitive satellite design project with TUSAŞ' s equity.

- TUSAŞ identified as prime contractor by Defense Industry Execution Committee in 2005.

- Projects intended to develop space subsystem are created. Moment Control Gyroscope developed to satellite tendency control.

- Cooperation with domestic corporations, establishments and institutes are being built for domestic military and civil satellite projects, which expected to be on the agenda in future.

- In Göktürk project, with Telespazio and Thales Alenia Space Companies, TUSAŞ, as main local, ensures participation in work packages including design, analyze, producing, integration and tests.

- Space Systems Integration and Observation Center will be operated by TUSAŞ. All tests for affects satellites could be exposed in space or during launching will be made. Göktürk 1 satellite handed from France and works about Göktürk 3 will start. Services for other countries’ projects will be given here.

- Works for establishing National Satellite Montage, Integration and Test Facility started with Göktürk projects in 2010 and became active in late 2012.

6. ITU Research and Application Center for Satellite Communications and Remote Sensing (CSCRS) Activities:

- CSCRS established as remote sensing system under the name of ITU-SAGRES in 2000 and became a center in 2003.

- Data accumulation from SPOT-2, SPOT-4, RADARSAT-1, ERS-2, NOAA-11, NOAA-14 and METEOSAT satellites.

TÜBITAK SPACE, started to National Ground Station Developing Project (Milli Yer İstasyonu Geliştirme Projesi (MIYEG)), to develop a national ground station for ground observation satellites and supply a station for observation satellites will be launched in the years ahead. Introduces in the opening meeting in 18 February 2015, MIYEG Project, will beperformed by TÜBITAK SPACE with MSB R \& D and Head Department of Technology's Coordination and Ministry of Development's incentive. The project aims to design, produce, test and integrate more systems about ground stations by local means. These aims will be made by in the leading of TÜBITAAK SPACE and local sub-contractor industry establishments. In scope of the project, ground station system with capability of communication on X and S bands will be developed. Feed, reflector and frequency selective surface, loco motor system, ground station control system (station and aerial control system), communication, monitoring system and relevant module and software are included in the project and the project is expected to be completed in 2019 (Tübitak UZAY, 2015a).

Led by TUBITAK SPACE, TURKSAT 6 Communication Satellite Project will be made with TUSAŞ, ASELSAN and CTECH companies, signed in 15 December 2014. The coverage area of TURKSAT 6 will include Europe, Asia and North Africa and the weight of the satellite will be 4 tons. Satellite will be placed in 36.000 kilometers above the ground in 42-degree east longitude ground constant orbit. There will be 4 backups, total 20 transposes on the satellite and the service life will be 15 years. Space history will be transferred to many subsystems used on the satellites and these subsystems will make substructures of national communication satellites in future. Along with putting TURKSAT 6A satellite on service, local and foreign television channels signal transmission, mobile communication, land, sea and air vehicles communications, Internet, data transfer and 
emergency call service will be provided. Turkey will be one of the 10 countries producing its satellite with completing this project (Tübitak UZAY, 2015b). See the Turkish road map for space operations since from 1994 to 2020 in Figure 2.

Currently, up to 500 people works in space field in Turkey. It is vital to have test and evaluation subsystems to support these studies. Essential of space studies is being an important member of qualified international cooperation, attain a place in space studies as a country and became a data generator. Turkey can only be a power in space field and high technologic with having these essentials. Table 3 shows the primary education institutions on space in Turkey. In scope of works intended to develop labor force, Istanbul Technical University and Middle East Technical University formed Aeronautics, Aircraft and Space Engineering departments. Due to Satellite technologies hold multi-disciplines within, other engineering disciplines started to be active in satellite technologies field to develop labor force. Istanbul Technical University, competed "cubesat" class satellite named ITUpSAT-1 and launched to the orbit.

Currently, $25 \%$ of requirements for developing and producing a satellite system are fulfilled domestically. From today to 2020, an improvement to 50\% in projects operated with TUSAŞ-TAI leadership, collaborating with domestic institutions and establishments, will be a positive progress. After 2025, it is estimated that subsystems and equipment improved domestically within TUSAŞ-TAI’s prime contracting usage rate will be 65\%.
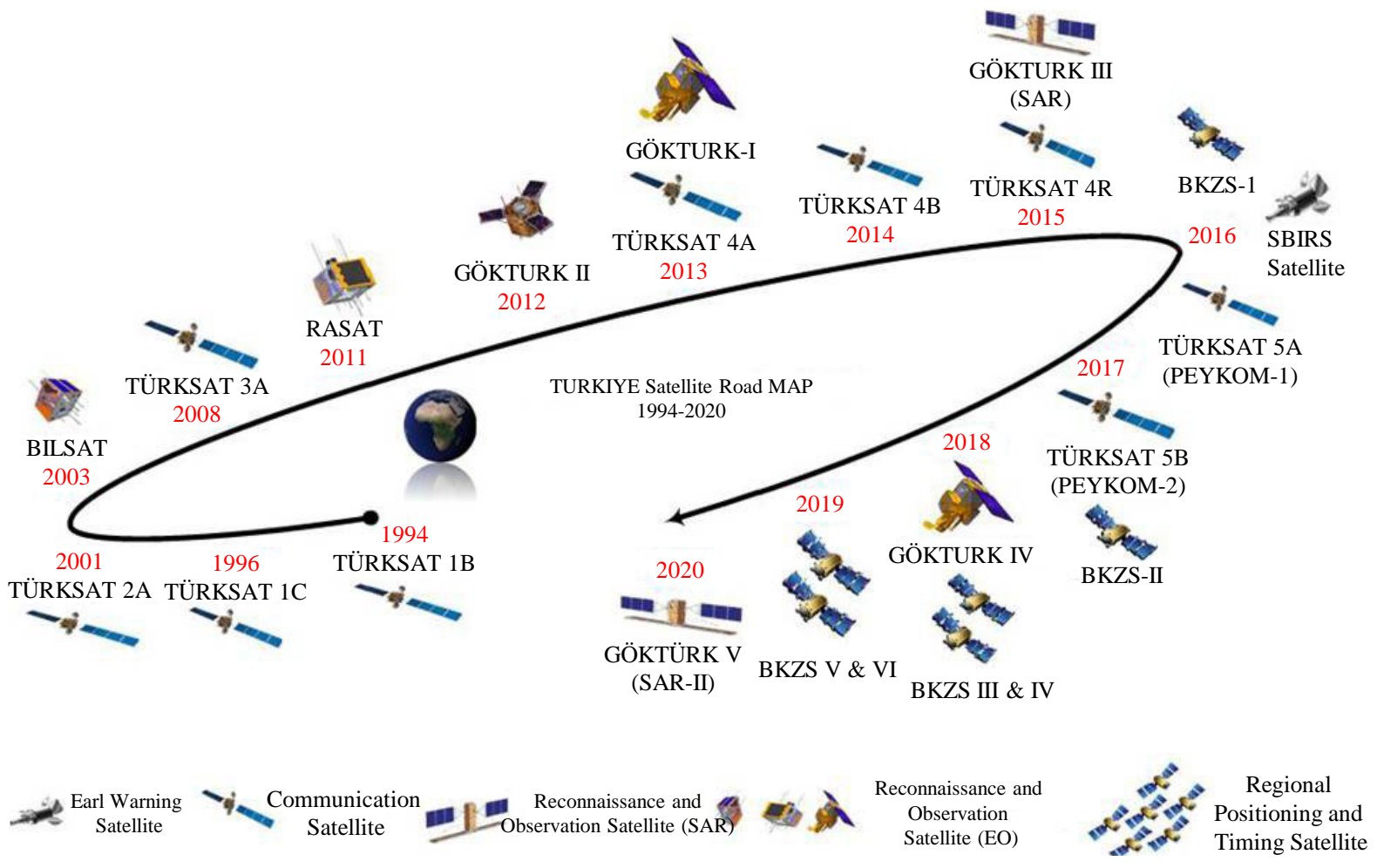

Figure 2. Space road map example for turkey. Source: Yılmaz BA, Türkiye ve Uzay Çalışmaları. inYılmaz S (Edt.), Uzay Güvenliği. İstanbul: Milenyum: 2014:145.

Table 3. Turkish space education institutions.

\begin{tabular}{ll}
\hline Main Institution & Elements \\
\hline TÜBİTAK & Space Technologies Research Institute (TÜBİTAK-SPACE) \\
Istanbul Technical University & Aircraft and Space Engineering Department \\
& $\begin{array}{l}\text { Research and Application Center for Satellite Communications and Remote } \\
\text { Sensing }\end{array}$ \\
Middle East Technical University & Aircraft and Space Engineering Department \\
Turkish Air Forces & Aviation and Space Technologies Institution \\
\hline
\end{tabular}


To improve domestic capability, it is important to conclude already initiated satellite projects on time and successfully. Putting products from the new project effectuated afterwards the completed project on practice, evaluated as serving development for technology and subsystem without an interruption. It is necessary to establish Turkish Space Institution to ensure coordination between projects, to track space activities and to be responsible for space studies. An example for Turkey's space road map is in the Image 1. Various delays happened in the plan for some satellites' put in use. But, a significant need for satellites in Turkey exists, until 2020.

\subsection{Space Industry in Turkey}

Keystones for constant space policy within a country are independent, private and civil industry devoted to this field. Military sector is also in the position of investing as much as possible to space technologies to accelerate access to space and making space used in the direction of citizens and national interest. Presently, there are only a few industry establishments specialized about space and producing space technologies. Some of the companies working in space technologies field:

- TAI, TUSAŞ Aeronautics Industry:

TUSAŞ became one of the world's 100 largest defense companies today and made big investments within last 12 years. Constitutively established for producing rotorcrafts and fixed wing crafts and specially for producing F-16 war crafts for Turkish Air Forces, TUSAŞ shifted its activities to producing satellites in recent years. TAI is still working on 2 big satellite-producing project; Göktürk 1 and Göktürk 2. TAI cooperates with TÜBİTAK SPACE Institute in Göktürk 2 Project. On the other side, in scope of Göktürk 1 project (this project more of a directly purchasing project), TAI works as subcontractor of Italian Company Telespazio, the prime contractor of the project. TAI gained very important capabilities by making important subsystem investments to space technologies and specially satellite systems.

- ASELSAN

ASELSAN is Turkey's Military Electronic Company. ASELSAN made a mark in the world by producing electronic components for military use. Rather than radar and other electronic military products, ASELSAN isknown in the world for its electro-optic products and sensors. ASELSAN is one of the main players on space technologies in Turkey and demanding its rights. ASELSAN wants to strive with satellite platforms and satellite ground systems for satellite duty systems.

\section{- ROKETSAN}

Deals with impulsive systems in space practices. ROKETSAN has very firm knowledge and experience on rocket systems with solid fuel and wants to extend this knowledge to satellite impulse with liquid fuel. ROKETSAN has not directly experienced space duty systems up to now but determined to present something on this field as soon as possible.

- TURKSAT

TÜRKSAT has mainly experienced on communication satellites, especially purchasing and operating Türksat satellites. These satellites used for countrywide television and radio broadcast and telephone communications. Lately, Türksat made a decision on attending research and developing activities about space technologies.

- USET Center

Defense Industry Undersecretaries and TURKSAT S.A. afford USET Center's capital cost, and established in scope of Göktürk 1 Project on site of TUSAŞ. Thiscenterwill enable to create an area for mechanical, thermic, acoustic, and electromagnetic interactions and to make qualification tests. In the center, mounting Göktürk 1 satellite and Turkey's first local satellite Türksat-6A, and advanced integration environmentaltesting will be made (Hürriyet, 2015). USET Center started to be built in 29 October 2011 and opened in 20 May 2015.

Turkey is at the beginning level in space studies rather than its place in space industry. Moreover, having regard to fact that these studies are limited to some universities and institutions, such as TÜBİTAK, our biggest problem is to industrialize these studies, in other words, to syndicate. As the first academician to organize space studies in Turkey in 2009, the words of English Professor, who attended to the symposium, Michael Sheen's still occurs to author: "It is hard to understand a country with a moon and a star in its flag but this unconcerned to the space" (Yilmaz, 2014). Turkey took important steps by sending communication satellites purchased from overseas in early 2000 and later designing and producing its satellites. Produced satellites', such as RASAT (discovery) and Göktürk 2 (Observation), most important pieces like camera systems handed from South Korea and other countries. On the other side, yes, effort made to develop independent satellites but there was no "laun- 
ching” capability and still there is not. RASAT sent from Russia and Göktürk 2 sent from China to space. Today, works for building a launching base in Muğla (to southwards) is still at project phase.

If we were to do a ranking of the space development of the countries in the world; USA, Russia, China and European Union would surely be in the premiere league. These countries produce and operate their satellites, have control of space, are capable of launching, developed their own global positioning systems. (GPS, GLONASS, COMPASS, GALILEO) Below the premiere league, there is first league, which contains India, South Korea, Brazil and Israel. Especially India, which is closest to premiere league by breaking through and developing its own global positioning system (IRNSS) in last few years should be taken as an example for our country. India has taken space studies beyond the security necessities, to every field of life. Lots of services in many fields such as communication and health service are now operated by the capabilities based on space. Brazil on the other hand, was also close to premiere league but due to wrong steps taken in last few years, their space studies are slowed down. The main reason stops Brazil and India is that they both are not capable of launching. You must be able to send your satellite to space and to place it on the orbit. Turkey fell from first league to second league, due to developments within TÜBİTAK.

In Turkey, space studies are limited with the exception of the interest of few establishments initiated by TÜBİTAK (Turkish Air Forces etc.) and some universities. Some important steps have been taken by these establishments to produce technologies and develop independent space capabilities. Turkey lost 15 - 20 years recently due to the developments in TÜBITTAK, which have politicized other establishments. Functions of USET (Uzay Sistemleri Entegrasyonve Test Merkezi) founded on 21May 2015, are installation, integrations and to test satellites. The more this center works, the more of the requirements of substructure can be covered. Although the main deficit of Turkey is that the interlocutor is not determined, in other words the lack of Space Agent. Turkey can constitute a consortium like European Union, for developing a global positioning system (GPS). Special code systems can be developed in order to avoid the usage with national intentions when necessary.

Turkey should take steps explained below to have a key role in space activities and to have independent space technologies.

\subsection{National Space Technologies Ownership Policy}

Space and Technology Ministry should be established and gaining space technologies must be a government policy. Continuity is important in technology. Technology must be kept off any populist approach and be supported constantly. It is not possible to think support is disturbed or avoiding cooperation with other countries due to political interests. Today, countries economic power is measured by their technologies.

\section{Establishing Turkish Space Agency}

Aeronautics and Space Technologies General Directorate established under the Transportation, Marine and Communication Ministry in November 2011. But, to have space technologies, Turkish Space Agency must be established erewhile. An institution to protect country's space matters and to guide national space policies is a necessary. Turkey worked on this for long years. Since 1995, many bill drafts prepared to establish Turkish Space Agency, but unfortunately, these bills did not conclude.

\section{Building a launching base to have national capability}

Every country must have a launching base to have easy and independent access to space. An independent launching base provides advantage to the country in the space race. Turkey's distance to equator and the used flight strips for placing on orbit crosses over neighboring countries limits launching duties. Only technological improvements can disable these limits.

\section{Education Need for Space Science and Technologies}

Current education institutions in Turkey are inadequate to create a well-adjusted space access program. There is a need for well-trained and expert employees. Masters and $\mathrm{PhD}$ programs and special programs for this subject must be created. To achieve higher educated labor, primarily number of university instructors must be increased. New education methodologies must be improved to encourage space education. Distance education and e-learning must be supported for broader and total education of space technologies. Investments on space technologies will eventually effect on improvement of internet and e-learning tools.

\section{Creating Awareness}

With no doubt, one of the main actors of space activities is creating awareness. Society must be informed about space and space technologies. These activities should be supported with various occasions, such as; sum- 
mer camps, short courses, seminars, exhibitions, museums and etc. Specially, it is important to reach the youth part of the society at the first base and awareness must be given at the beginning of their education. Turkish people are curious about space. If proper conditions are provided, a high potential on this working field can be created. For these reasons, encouraging of spreading space studies to society, inventiveness, knowledge and technology improving on the basis of people is important.

Industry Intended to Space

At the present, there is only a few industry establishments specialized on space and producing space technologies in Turkey. It is necessary for these institutions to increase their number as soon as possible and to exceed a particular sill level. Moreover, these institutions must specialize on space technologies and sciences. In Turkey, human labors on space studies are around 300 - 400 in total. Turkey has intention and soul for space studies but it must be improved. There should be institutions and companies for Space Department graduates from universities such as Middle East Technical University and Istanbul Technical University.

\section{SMEs on Satellite Systems}

SMEs (Small and Medium Scale Enterprises) are indispensable pieces of well and settled space industry. Therefore, it is not possible to expect a well-adjusted space programs without SMEs. SMEs are essential for creating a synergy on space activities. SMEs can work as sub-contractor for simulation, software development and modeling on space activities. Also, SME's are essential for all kinds of creativity to occur with new ideas and inventions. Companies such as TAI should be taken as an example and lead up the way for other companies. Like in the Defense Industry, only client of these companies will be government, and it must promote corporates by its regulations.

\section{Conclusion}

Turkey's intention on space and satellites started quite later than developed countries. However, Turkey gained a position as satellite and satellite sub-system developing country in the world classification of active countries with initiated space projects. The most critical issue about space is access. Turkey must attain progress by collaborating domestically and overseas to become one of the satellite launching countries. International cooperation is important in the field of space but some capabilities must be national due to national securitization problems. If we take a look at the point where Turkey becomes in space technologies, despite its lacks, an important technological level is seen. Seasoned and qualified labor and revealing sub-system capabilities are enabling future satellite needs to be fulfilled domestically in a large extend. Like in all developed countries, it is important to establish an institution (Turkish Space Institution) to set a vision for the government, dominate country's space policy by defining space capabilities on universities, industries, public and civil area. With this establishment, improvement of space industry will gain acceleration.

Space Agency will be focused on determining and tracking space strategies and improvement of sub-system and human capability, for this reason, project must go beyond the pre-electoral promises of the political parties. Proper solutions should be found via civil and military wings for structure and work of the Space Agency. Turkey course of action is Göktürk 3 and 4, space-launching center, activating USET, Turkish GPS and technology improvement in the computer-camera field. Technology is not sufficient but also not in a bad situation, Turkey can take big steps soon by investing human labor. Presently, high technological production and exportation development preferred rather than financial capitalism and traditional production development models. Turkey, just as India, could make space studies the most important factor of development model based on high technology and use technological developments procured in this field for increasing national income and staffing capabilities, and gained an advantage on catching up other countries and current affairs. Country's welfare would increase and national security would be provided unless dominating the space, using space area actively and became self-sufficient in the space.

\section{References}

Aslan, A. R. (2014). Where Are We in Space Discovery? (UzayKeşfininNeresindeyiz?) Al Jazeera. http://www.aljazeera.com.tr/gorus/uzay-kesfinin-neresindeyiz

Davenport, C. (2015). A New Space Race Emerges as NASA Prepares to Award Contract to Ferry Supplies to Space Station, the Washington Post.

https://www.washingtonpost.com/news/the-switch/wp/2015/03/09/a-new-space-race-emerges-as-nasa-prepares-to-award-c 
ontract-to-ferry-supplies-to-space-station/

Department of Defense (2004). National Security Space Acquisition Policy, “Guidance for DoD Space System Acquisition Process" Number 03-01. Washington, DC: US Department of Defense.

Eisenhower Institute (2004). Space Security 2003. Washington D.C.

FM 3-14 (2005). Space Support to Army Operations (pp. 1-2). Washington D.C.: U.S. Land Forces.

Erturan, A. F. (2014). The New Army of Turkey; Founding of Space Forces (Türkiye’ninYeni Ordusu “Uzay Kuvvetleri” Kuruluyor), Star Gazete. http://haber.star.com.tr/teknoloji/turkiyenin-yeni-ordusu-uzay-kuvvetleri-kuruluyor/haber-897898

Gouveia, W. J. (2005). An Assessment of Anti-Satellite Capabilities and Their Strategic Implications. Astropolitics, 3-2, 176. http://dx.doi.org/10.1080/14777620590967208

Göker, Y. (2003). The New Vision of Air Forces (HavaKuvvetlerininYeniVizyonu). Journal of Turkish Air Forces, 243 , 8-9.

Harding, R. C. (2013). Space Policy in Developing Countries (pp. 1-2). New York: Routledge.

Hürriyet (May 21, 2015). Turkey Opens First Satellite Center (Türkiye’nin İlk UyduMerkeziAçıldı).

Jaramillo, C. (2010). Space Security 2010 (p. 1). Ontario: Pandora Press.

Jones, M. (May 18, 2015). Falling to Earth: Is Russia’s Space Industry Dying? National Interest. http://nationalinterest.org/blog/the-buzz/falling-earth-russias-space-industry-dying-12911

Jones, M. (December 9, 2014a). Asia’s Space Race Is Underway. The Interpreter, the Lowy Institute for International Policy. http://nationalinterest.org/blog/the-buzz/asias-space-race-underway-11819

Jones, M. (December 5, 2014b). Space: America’s Forgotten Fronties. The Interpreter, the Lowy Institute for International Policy. http://nationalinterest.org/blog/the-buzz/space-americas-forgotten-frontier-11794

Lewis, J. (2004). Space Weapons in US Defense Planning. INESAP Bulletin No.23.

Linster, B. (2009). Space and the Economy. In D. Coletta, \& F. T. Pilch (Ed.), Space and Defense Policy (p. 55). New York: Routledge.

MacDonald, B. (2009). A Prohibition on the Testingand Use of Debris-Causing Kinetic Energy Anti-Satellite Weapons in Conference. Space Security 2009: MovingToward a Safer Space Environment, 15-16 June 2009, Geneva.

Pasco, X. (2009). Toward a European Military Space Architecture. In D. Coletta, \& F. T. Pilch (Ed.), Space and Defense Policy (p. 1). New York: Routledge.

Pillar, P. (2014). Space, the Final Frontier between the Public and Private Sectors. National Interest. http://nationalinterest.org/blog/paul-pillar/space-the-final-frontier-between-the-public-private-sectors-11603

Putrich, G. S. (2008). High-Tech Satellites Breed Higher Expectations. Defense News.

Tübitak UZAY (2015). Bilim ve Teknoloji Yüksek Kurulu Onbirinci Toplantısı, Gelişmelere İlişkin Değerlendirmeler ve Kararlar (pp. 63-100). http://www.tubitak.gov.tr/tubitak_content_files/BTYPD/btyk/11/11btyk_karar.pdf

TÜBİTAK UZAY (2015a). Türkiye'nin İlk Yerli Yer İstasyonu Projesi TÜBİTAK UZAY'da Gerçekleşiyor. http://uzay.tubitak.gov.tr/tr/haber/turkiyenin-ilk-yerli-yer-istasyonu-projesi-tubitak-uzayda-gerceklesiyor

TÜBİTAK UZAY (2015b). İlk Milli Haberleşme Uydusunda İmzalar Atıldı. http://uzay.tubitak.gov.tr/tr/haber/ilk-milli-haberlesme-uydusunda-imzalar-atildi

West, J. (2008). Next Generation Space Security Challenges. In UNIDIR, Security in Space: The Next Generation, 31 March-1 April 2008, Geneva, 35.

Wirtz, J. J. (2009). Space and Grand Strategy. In D. Coletta, \& F. T. Pilch (Ed.), Space and Defense Policy (pp. 25-26). New York: Routledge.

Yılmaz, B. A. (2001). Space and Its Military Dimension (Uzay ve Askeri Boyutu). The 1st International Space Symposium (pp. 8-20). Ankara: Turkish Air Forces.

Y1lmaz, S. (2014). Space Security (Uzay Güvenliği) (p. 3). Istanbul: Milenyum. 


\section{Submit or recommend next manuscript to SCIRP and we will provide best service for you:}

Accepting pre-submission inquiries through Email, Facebook, LinkedIn, Twitter, etc.

A wide selection of journals (inclusive of 9 subjects, more than 200 journals)

Providing 24-hour high-quality service

User-friendly online submission system

Fair and swift peer-review system

Efficient typesetting and proofreading procedure

Display of the result of downloads and visits, as well as the number of cited articles

Maximum dissemination of your research work

Submit your manuscript at: http://papersubmission.scirp.org/ 